\title{
Knowledge of child development in the interface of theory and practice in foundation phase teacher education
}

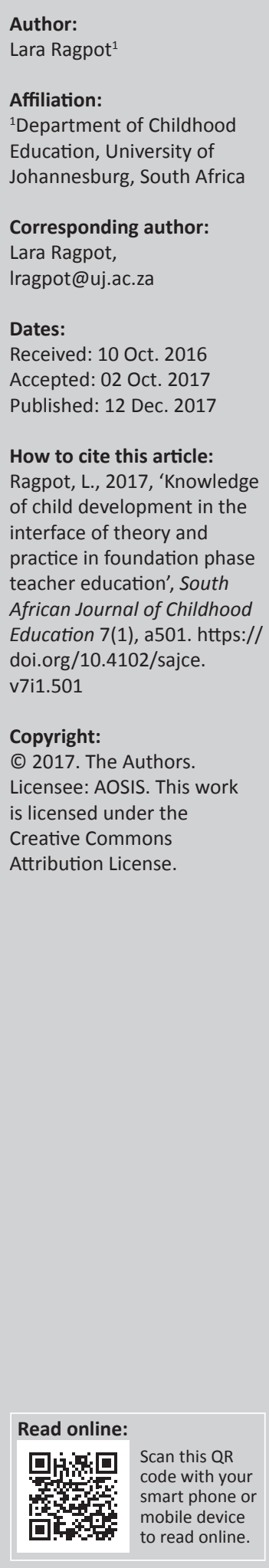

How the child develops and learns should be an integral part of pre-service teacher education programmes. This article argues that for foundation phase teachers to teach young children effectively, course content in initial teacher education (TE) should cultivate a thorough understanding of the developing child by infusing theories of childhood development into coursework and practicum. To strengthen this argument, the article gives examples of international TE programmes which recognise that child development should take preference in these programmes. However, for the future teacher to really know the developing child and how to intervene when optimal development is not in place, the theories on child development taught in coursework need to be done in tandem with practical work in a school classroom. This theory-practice interface in initial TE could be optimally supported in a foundation phase pre-service TE programme, which utilises a university-affiliated teaching school as site for practical cross articulation of coursework theory.

The average South African (SA) foundation phase (FP) teachers are faced with many challenges in their day-to-day teaching. Not only do these teachers need to adhere to the minimum outcomes required from a very extensive and fast-paced curriculum (in its third iteration in 10 years: Carl 2008; De Villiers 2011), but they are also overwrought with paperwork (Deacon 2010). In an effort of the South African Department of Basic Education (SA DBE) to ensure that quality education takes place in FP classrooms, teachers need to constantly do administrative reports that show evidence of their teaching in written accounts of work. This is supervised by school management and district officials focused on sufficient curriculum content delivery, often performed during inspection via school and class visits. Despite this busy-ness of providing proof that educational outcomes have been reached according to curriculum specifications, the teachers should somehow still maintain sufficient interaction with the children in their classes and make sure that learning is taking place. Unfortunately, despite all the stringent reports that schools have to provide to government on the South African School Administration and Management System (SAMS) [Gauteng Department of Education (GDE) 2017], and policies of support put in place on national level [Draft Policy on Screening, Identification, Assessment and Support (SIAS), DBE 2014], many children are still falling by the wayside of receiving optimal teaching and learning support. Molefe (2014) asserts that too many learners ${ }^{1}$ per grade are referred either for possible failure (thus repeating the grade) or for assessment by overtasked special educational services in the SA education districts.

An education specialist ${ }^{2}$ in a typical Gauteng province district office is obliged to provide educational support to as many as 22-30 schools per year. Amongst the services that they offer is training of School Based Support Teams (SBSTs), assessment of learners for possible placement in special education, counselling of learners who have experienced trauma or present with emotional difficulties, and meeting with parents. Even in a single school this is a monumental task for one person to maintain; in 20 schools or more, an impossible feat. Because of this high volume of work, these support specialists are not able to provide optimal intervention to all the children referred to them. Because of high case load, they only focus on worst-case scenarios where children present with severe learning difficulties, such as possible cases of acute cognitive impairment (R. Vangile, pers. commun., 08 August 2014). Children who present with mild difficulties and who are in need of some learning support are mostly retained in the grade for

\footnotetext{
1.Learner is the term used for children in basic education in South Africa. The term student mainly refers to a student at university or tertiary level.

2.Senior Education Specialists (SES) and Deputy Education Specialists (DCES) work with special educational needs in the Gauteng
} Department of Education (GDE). 
another year, in the hope that the repeat will address their difficulties. This repetition in the grade often happens without any focused support (except from the class teacher) to address the learner's difficulty, which means that the child is merely repeating a year without his or her disability being addressed in a specialised manner. As the child is not allowed to repeat a grade more than once in a phase, ${ }^{3}$ these learners are often passed along the grades. In this manner, many children enter intermediate (middle) school with very few foundational skills in basic literacy and numeracy (Howie \& Van Staden 2012). In fact, Spaull (2016) reports that the SAQMEQ III Grade 6 results (Spaull 2011) show that $27.3 \%$ of Grade 6 learners in South Africa are functionally illiterate. It is evident from the stated facts that specialised educational support systems simply do not have the workforce to address difficulties that young children present with, on a large scale. Most intervention and support then becomes the sole responsibility of the class teacher, who often feels underresourced, but also ill-equipped with suitable knowledge to address children's presented learning and developmental difficulties.

In my role as an educational psychologist, I often present workshops to teachers teaching in the FP. One of the main issues raised by teachers during these workshops and training sessions is that they feel inadequately equipped in their knowledge of theory and practice to address childhood developmental and learning difficulties in their classrooms. Most of them report that the little they know, they had gathered in a rather ad hoc manner by attending training workshops and searches on the Internet. Most of them report that they believe that their initial teacher training (ITT) did not proficiently prepare them to deal with developmental and learning issues in the classroom. They almost always voice their desire to have had more time spent during their preservice teacher education (TE) to learn more about childhood development. A lack of knowledge is confirmed by Spaull (2016), who identifies two binding constraints in progress in education in South Africa: lack of accountability and lack of capacity, where lack of capacity refers to, amongst others, teachers' lack of skills to fulfil their job description. This identified gap in knowledge and skills focuses attention on ITT for a possible solution. Educating future teachers to know how children learn and develop, and how to apply suitable intervention strategies if these children present with difficulties, should take preference in initial TE programmes.

In this article, I will focus on the current efforts in higher education in South Africa to produce a more knowledgeable FP teacher who is equipped with the necessary skills to teach effectively in this specific phase, where children are at the optimal level of development of many crucial skills for future learning at school (Blair \& Razza 2007). To strengthen this argument, I will give examples of TE programmes globally, which have recognised the need for the future teacher to have a more in-depth knowledge of child development. 3. In South Africa, basic schooling happens in four phases. Foundation phase (Grades
R-3), Elementary phase (Grades 4-6), Senior phase (Grades 7-9) and Further Education and Training (FET) phase (Grades 10-12).
However, I will also argue that even though these programmes focus more on including child development courses in their initial TE, the knowledge taught in theory in these courses is not explicitly articulated into practicum experience in a classroom setting, thereby highlighting the need for more theory-practice interface (Gravett, Henning \& Eiselin 2011), where pre-service teachers see the theory come 'alive' in the practical classroom situation. I will then argue that a university affiliated teaching school provides for an ideal setting for pre-service TE students to cross articulate theory of childhood development in practice in a classroom environment with children (Henning \& Gravett 2011). This engenders a more knowledgeable teacher who could answer to the current needs of FP teaching in the country.

\section{The need for curricular reform in pre-service teacher education}

In surveys of top performing schools, the first three years of educational performance are identified as the single most powerful indicator of subsequent school success (Barber \& Mourshed 2007; Gravett, Morgan \& Henning 2009). To optimise academic success in the future, young South African children need teachers who are competent and who know how children develop and what young learners' early theorising about concepts imply for instruction and for care (Carey \& Johnson 2000; Daniels \& Shumow 2003). Preparation of knowledgeable foundation teachers, who will enter the education system, is an important avenue to redress poor education practices in the many underperforming schools in the country (Gravett \& Petersen 2017). To produce this type of teacher, all eyes turn towards TE institutions.

Education authorities are looking to universities to ensure that the new generation of teachers will be of high quality (Green et al. 2011). The expectation is that universities will deliver teachers who are knowledgeable on a wide array of theories and who are also competent in their everyday pedagogy, using such theories to enrich their work. To produce this type of novice teacher is, however, not an easy feat, as attested by volumes of both international and local South African research results (Arends \& Phurutse 2006; Darling-Hammond 2001; Gravett et al. 2011; Henning \& Gravett 2011; Kardos \& Johnson 2007; Snow, Griffin \& Burns 2005). Table 1 shows South Africa's guidelines for curriculum design and development for FP TE (according to the Department of Higher Education and Training - DHET).

The emphasis the guidelines place on a future teacher's ability to know and guide the child's learning (as placed in italics in Table 1) is quite clear. If TE institutions want to adhere to the guidelines of the DHET, and deliver the type of teacher needed to fulfil the roles as stipulated in the guidelines, knowledge of children's learning and how to successfully espouse their learning in the classroom should take preference in TE programmes. This means that when novice teachers exit pre-service TE programmes, they need to have a good foundational knowledge of childhood development and learning and how to apply suitable interventions to support 
TABLE 1: Department of Higher Education and Training guidelines for curriculum design and development for the teacher education in the foundation phase. Types of learning The teacher should

\begin{tabular}{|c|c|}
\hline Disciplinary & $\begin{array}{l}\text { - have sound subject knowledge } \\
\text { - } \text { know who their learners are and how they learn } \\
\text { - manage classrooms effectively } \\
\text { - reflect critically, in theoretically informed ways } \\
\text { - work together with prof essional community of colleagues }\end{array}$ \\
\hline Practical & $\begin{array}{l}\text { - know who their learners are and how they learn } \\
\text { - know how to communicate effectively } \\
\text { - have highly developed literacy, numeracy and IT skills } \\
\text { - be able to identify learning or social problems } \\
\text { - manage classrooms effectively } \\
\text { - assess learners in reliable and varied ways }\end{array}$ \\
\hline Situational & $\begin{array}{l}\text { - know who their learners are and how they learn } \\
\text { - know how to communicate effectively } \\
\text { - be able to identify learning or social problems }\end{array}$ \\
\hline Fundamental & $\begin{array}{l}\text { - know how to communicate effectively } \\
\text { - have highly developed literacy, numeracy and IT skills } \\
\text { - manage classrooms effectively }\end{array}$ \\
\hline Pedagogical & $\begin{array}{l}\text { - know how to teach } \\
\text { - know who their learners are and how they learn } \\
\text { - have sound subject knowledge } \\
\text { - be able to plan and design suitable learning programmes (PCK) } \\
\text { - be able to identify learning or social problems } \\
\text { - manage classrooms effectively } \\
\text { - rssess learners in reliable and varied ways } \\
\text { - work together with their prof essional community of colleagues }\end{array}$ \\
\hline
\end{tabular}

children's development and learning in the classroom. In order to engender this focus on childhood learning, it is firstly important for courses on childhood development to be included in teacher preparation programmes (Korthagen, Loughran \& Russell 2006). But equally important should be careful consideration of where and how these courses are presented within the overall TE programme.

\section{Childhood development and learning in teacher preparation programmes - An overview}

Most developers of TE programmes include courses on child development in their curricula (Korthagen et al. 2006; NICHD \& NCATE 2006; Oduolowu 2009). Many of these programmes seem to be developed on the premise that if a course on cognitive development is included in a programme, the students will know in the future how to design activities for optimal learning in the classroom (Daniels \& Shumow 2003; NICHD \& NCATE 2006; Rimm-Kaufman \& Hamre 2010).

In the United States, much attention has been given to inclusion of child development courses into initial TE. From December 2005 to March 2006, the National Institute of Child and Human Development (NICHD) and the National Council for the Accreditation of Teacher Education (NCATE) in the United States held round table discussions to determine the most relevant principles and themes of child development that should be incorporated into teacher preparation programmes. Their findings were published in a Summary of Roundtable Discussions (NICHD \& NCATE 2006), in which they attempted to capture the most important areas of knowledge and practice of childhood development (including neural, cognitive, social, psychological, physical and ethical development) that impact on teacher preparation programmes. In preparation for the work of the NICHD/NCATE roundtable discussions, NCATE conducted a survey of its accredited institutions. One of the purposes of the survey was to gather information on how knowledge of child development is transmitted to students during TE programmes. Their findings indicated that at $90 \%$ of the institutions, teacher candidates are required to take at least one child development course; approximately $80 \%$ of responding colleges of education offer courses in child and adolescent development and they indicated that these courses are offered through their psychology departments; and about half of the responding institutions thought that additional coursework was needed (NICHD \& NCATE 2006:7). The survey indicated that the textbooks that were used during these courses were mainly purely psychological, with little classroom application. In the courses that were taught within the education departments of the colleges, it was found that the professors made up their own examples and case studies to cross-articulate the theories to the school classroom. In the psychology departments, this cross-articulation was, however, lacking. One of the main recommendations for the improvement of courses on child development in teacher preparation programmes taken from the Roundtable Discussions is that:

Departments of psychology and education should work together to adapt course materials for an educational setting, to show teacher candidates how to apply the findings of developmental research in the classroom, and to help inform the development of appropriate content standards. Such an approach may work within the carrying capacity of a preparation program and holds the promise of preparing candidates for the realities of teaching in the school context. (NICHD \& NCATE 2006:29)

The participants in the discussions accentuated the fact that pre-service teachers are not able to automatically transfer information about childhood development course texts into classroom practice - they need to be shown how. They propose that TE programmes need additional modules on child development that are embedded longitudinally in the course of a TE program: 'Teachers need a working knowledge of the principles of child development in order to master the techniques that enable students to learn to high standards' (NICHD \& NCATE 2006:4). Thus, the call is for teacher educators to provide students with a curriculum that is 'both philosophically valid and personally interesting to them' (Gilbert 2005:4).

Across the Atlantic in Norway, individual TE institutions are responsible for developing courses in line with the goals and structure of the national framework, referred to as 'the Norwegian framework', and TE institutions are expected to produce their own curricula, but within the parameters set out by the framework (Stephens, Tønnessen \& Kyriacou 2004). Similarly to the United States, the Norwegian framework requires child development and learning to form part of coursework in TE programmes. However, another similarity with the United States is that in the courses on child development and learning theory and practice are not always interwoven. The Norwegian framework contains separate theory and practice sections called Educational Theory and Educational Practice (Stephens et al. 2004). 
Students thus learn about human learning within Educational Theory in a subsection called 'Learning and Development', but only do classroom application in Education Practice in a subsection called 'How to teach and how to lead learning' (Stephens et al. 2004:116). It is also interesting to note that in Norway, teacher educators seem to be focusing on the preservice teacher's meta-learning, as opposed to the United States where the focus is more on the classroom.

In England, the approach to integrating academic courses on child cognitive development into TE programmes seems to differ from the approach taken in Norway and the United States. Where Norway differentiates between theory and practice, the English TE system seems to have moved almost solely to a practical classroom-based approach. In a comparative study of policy goals of teacher training in England and Norway, Stephens et al. (2004) found that in the English policy document, ITT provides training for preservice teachers which is mainly focused on the 'practical skills of teaching' (Stephens et al. 2004:110), with a marked reduction of time devoted to academic study and moral debate. In England, ITT courses are obliged to meet with a series of competencies (called 'Standards') set by the English Department of Education (DfE) (Stephens et al. 2004:114). The 'Standards' (heavy on practice pointers, light on theory) are organised in three interrelated sections: (1) Professional Values and Practice, (2) Knowledge and Understanding and (3) Teaching. The pre-service teachers learn about physical, cognitive, affective and social development in the Knowledge and Understanding section. This knowledge of developmental theories is constantly 'discovered' through practical classroom application or what Weber refers to as 'the facts of the matter as revealed through expert practical knowledge' (Weber 1968, in Stephens et al. 2004:112). Even though there is much practical cross-articulation, the question could be asked whether the pre-service students understand the theory within its greater complexities or just in terms of application.

In Africa, Esther Oduolowu's research focuses on the TE programme at one of Nigeria's main universities, the University of Ibadan (Oduolowu 2009). Her findings show that child development forms part of the TE programme, but that these courses are taught in collaboration within many departments (e.g. the Psychology Department and the Department of Special Education). Even though the university's effort to collaborate with other departments is commendable, this type of collaboration could hold both opportunities and difficulties. The students might get more exposure to a wider array of theories, but different departments could take different approaches when explaining notions posited by the different theorists. The students may benefit from this diversity. In contrast, it might be in this diversity, where differences in approaches taken by various departments, where students could experience difficulties. Students might find it difficult to coalesce the dissimilar approaches that different departments may take in their interpretation of theories.
This is exactly what Smagorinsky, Cook and Johnson (2003) argue when they propose that different departments that teach in TE programmes do not always share common understanding of concepts and that can become very confusing to students. They refer to this as a 'conceptually haphazard teacher education preparation' (Smagorinsky et al. 2003:1422), which results in students having different conceptions and also inconsistencies amongst these conceptions. They furthermore argue that if universities want to teach courses on childhood development in different departments, these departments need to have a 'consistent focus on a pedagogical approach or teaching philosophy' (Zeichner \& Gore 1990, in Smagorinsky et al. 2003:1422) for the course content to have the fully intended educational effect.

From this brief overview of TE programmes internationally, it is evident that TE courses form part of initial TE programmes, but that they are often taught in other departments and that articulation to classroom practice is seldom made (as in the United States), that there is too much application and too little theory (as in England) or that theory and practice are seen as separate courses (such as in Norway). I argue that what is needed is a strong focus on continuous cross-articulation of the ideas proposed in theory and the classroom application of these theories - this can only be done if childhood development courses are situated within the education faculty, where constant examples of the interface of theory and practice can form the central tenet of lecture discussions.

\section{A university affiliated teaching school as context for cross- articulation of theory and practice}

According to Smagorinsky et al. (2003), theory and practice are often seen as different domains in TE. Henning and Gravett (2011) argue that this need not be the case and that some epistemological integration is possible in pre-service TE. According to the perceived divide, theory is viewed as more 'ethereal and authoritative' and practice as more 'protean and pragmatic' (Smagorinsky et al. 2003:1400). The higher probability of theory improving practice is accepted and the likelihood that practice might be able to inform theory is never considered. Smagorinsky et al. (2003:1400) note that practice often takes the back seat to theory and practice is viewed to be something that 'people do in spite of what they think'. They are of the opinion that Vygotsky's notion of concept, which recognises the inherent relation between abstracted systems of principles and engagement in cultural practice, could be utilised to unify theoretical concepts and their application in practice.

If one accepts the proposition that the process of concept development is mediated by activity in cultural practice and that instruction in principles alone will not result in the advancement of a concept (Vygotsky 1978), then the training of teachers should be based on a conjunction of theory 
and practice. Theory divorced from application will not create an attentive relation between conceptual knowledge and experience in the world. Vygotsky (1978) argues that the interchange between formal knowledge of principles and knowledge gained through activity enables people to think and learn beyond their range of experience. Practice contributes to learning and thus to concept development, by working in dialectical relation with the principles that bring stability to the unity of concepts. Lave and Wenger (1991) in Smagorinsky et al. (2003:34-35) emphasise this when they argue that 'learning is not merely situated in practice ... learning is an integral part of generative social practice in the lived-in-world'.

University training courses of pre-service teachers should thus ensure that practice in a schooling environment serves as the worldly experience through which a concept expounded in theory is placed in its foundation, consistency and meaning. This then asks of courses to enable pre-service teachers with theoretical concepts which they will be able connect to their instructional practice. Thus, university courses should stay as closely linked as possible to the needs, values and goals of the school community. Smagorinsky et al. (2003) argue that if the theoretical concepts taught at a university level do not comply with school practices, they will not have a great impact on the new teacher's pedagogy when they enter schools:

The concept that the teacher learns in pre-service education is likely to recede or be reformulated in the light of new communities of practice that teachers become involved with at the schools in which they will teach. (Smagorinsky et al. 2003:1410)

University courses should thus aspire to approximate the courses as closely as possible to the reality of the schooling situation. This can only happen effectively if students do not only have discussions in lectures about this interface, but when they practically experience it in the classroom; there is no better way to do this than in a teaching school which is affiliated to the university.

At the University of Johannesburg (UJ), with the GDE, there is a partnership FP school (the Funda UJabule School) on the university's Soweto campus, which serves as a teaching school for UJ students. The programme at the university is regarded as innovative in the country as it is the first university where the students are doing constant practical work in classrooms in the teaching or 'laboratory school'. The Funda UJabule School (isiZulu for 'Learn and be Joyful') was built on the university's Soweto campus in 2009. It is unique as in South Africa there has not been a history of teaching schools affiliated with university training. It is during practicums at the Funda UJabule School that students experience hands-on practical knowledge integrated with theoretical knowledge in the different course components. In the teaching school classroom environment they also learn how disciplinary knowledge is transmuted into classroom practices - the last and most likely most important step to utilising knowledge about the developing mind of the child for classroom learning. This will be evident in their ability to translate theory into practice. I argue that preservice teachers have knowledge of childhood development and they constantly observe children in the educational classroom setting; it is likely that they also want to learn how to infuse it into their own practice for their future classroom. In other words, the focus for them must be on how to translate their disciplinary knowledge into pedagogical knowledge.

The organising framework of the FP initial TE programme at UJ is The Developing Child. This means that during their four years of initial TE bachelor's programme, students learn child development in six semester courses. These courses focus on holistic child development; physical, sensory and brain development; cognitive development and learning; socioemotional development; child development in the family; and intervention and support of children who present with difficulties in their development and learning. The theoretical learning in the courses is constantly supported by practical classroom engagement with learners in the Funda UJabule Teaching School. Thus, what students learn in theory in the coursework is observed and interrogated in practice in the classroom. The courses are presented by academics from the Department of Childhood Education (DCE) and the Department of Educational Psychology (DEP) both of whom are situated on UJ's Soweto campus. The academics from these departments are involved in constant practicum supervision of students in the school. The coursework presenters are thus constantly aware of what is happening in the Funda UJabule Teaching School and can use examples of child development in action that the students observe in the school classrooms in the lecture discussions. Theory practice interface in its essence is thus practiced. Reports from students who have exited the programme indicate that this constant theory-practice interface prepares them optimally for the demands they face in the classroom when they start teaching (Henning, Petker \& Petersen 2015).

The child development courses presented in this TE programme thus address the issues raised by teachers in practice as well as TE institutions as argued in the article: (1) The programme is steeped in child development - thus, the pre-service teacher is exposed to many different aspects of child development over the course of the programme. The students thus gain an in-depth learning about the developing child in many domains. (2) As students learn so extensively about child development and how to support children optimally who present with difficulties, they can address these difficulties within the classroom. In this way, in their future classrooms they will refer fewer children to special educational services, as the teacher is able to provide the necessary intervention and support in the classroom. (3) The child development courses in the programme are presented by academics who are involved in the TE programme in general and are constantly involved in practicum work in the teaching school in particular; the issue of the university coursework not being connected to real-life practical classroom examples is thus addressed. (4) Lastly, the students interrogate theory in coursework in the practical setting of 
the classroom at the teaching school, and thus a functional bridge is built to cross the theory-practice divide.

\section{In conclusion}

Teachers who have an in-depth knowledge of childhood development may be better able to teach for conceptual change and thereby engender children's future academic success. These teachers may be less mechanistic and develop a personal pedagogy that is geared to stimulate positive change. Their knowledge of childhood development therefore has a direct relation to their pedagogy. This has far-reaching implications for teacher preparation programmes to ensure that future teachers will exit these programmes with the necessary knowledge of childhood development. If pre-service teachers are taught coursework on child development throughout their initial TE programme, they will be more knowledgeable about childhood development across many domains. But added to this, if these pre-service teachers will be involved in constant practicum work in a university affiliated teaching school, they will be able to cross-articulate the theory learned in these courses to classroom practice. As they had spent time with children in the classroom while they were learning about child development in their TE programme, when they start teaching, they will be better equipped to: (1) know when and how the child learns and develop; (2) identify when the child is not learning and developing optimally; and (3) support and intervene when children present with developmental and learning difficulties. In this way, the lack of teacher capacity identified by Spaull (2016) is addressed in terms of these novice teachers' knowledge of, and ability to support, children's learning and development in the classroom.

\section{Acknowledgements}

The author received a bursary for her DEd study from the Department of Higher Education and Training/Teacher Education funding for the UJ project in the Strengthening Foundation Phase Teacher Education (2011-2013) programme. The author wishes to thank the project leader, Prof Elizabeth Henning, for her guiding role in the writing of this article.

\section{Competing interests}

The author declares that she has no financial or personal relationships which may have inappropriately influenced her in writing this article.

\section{References}

Arends, F. \& Phurutse, M., 2006, Beginner teachers in South Africa: School readiness, knowledge and skills, HSRC Press, Pretoria.

Barber, M. \& Mourshed, M., 2007, How the world's best performing school systems come out on top, McKinsey and Company, London.

Blair, C. \& Razza, R.P., 2007, 'Relating effortful control, executive function, and false belief understanding to emerging math and literacy ability in kindergarten', Child Development 78(2), 647-663. https://doi.org/10.1111/j.1467-8624.2007.01019.x

Carey, S.E., \& Johnson, S., 2000, 'Meta-representation and conceptual change: Evidence from Williams Syndrome', in D. Sperber (Ed.), Meta-representations: A multidisciplinary perspective, pp. 225-264, Oxford University Press, New York.

Carl, A., 2008, 'Teachers' experiences of change in South Africa: For or against?', paper presented at the Fifteenth International Conference on Learning, The University of Chicago, Chicago, IL, 2-6 June, 2008.
Daniels, D.H. \& Shumow, L., 2003, 'Child development and classroom teaching: A review of the literature and implications for educating teachers', Applied Developmental Psychology 23, 495-526. https://doi.org/10.1016/s01933973(02)00139-9

Darling-Hammond, L., 2001, Thoughts on teacher preparation, viewed 19 December 2010, from www.edutopia.org/ldh-teacherpreparation.

Deacon, R., 2010, 'Educating the educators: Challenges facing teacher education and development in South Africa', Focus, The Journal of the Helen Suzman Foundation $59,38-43$.

Department of Education, 2014, Draft Policy on Screening, Identification, Assessment and Support (SIAS), Government Printer, Pretoria.

Department of Higher Education and Training (DHET), 2010, Draft policy on the minimum requirements for teacher education qualifications aligned with the higher education qualifications framework, DHET, Pretoria.

De Villiers, R., 2011, 'Student teachers' views: What is an interesting life sciences curriculum?', South African Journal of Education 31, 535-548. https://doi. org/10.15700/saje.v31n4a403

Gauteng Department of Education (GDE), 2017, Circular 02 of 2017 - Guidelines of submission of data using SA-SAMS, viewed 02 September 2017, from http://www. education.gpg.gov.za.

Gilbert, J.K., 2005, Constructing worlds through science education. The selected works of John K Gilbert. World library of educationalists, Routledge, London.

Gravett, S., Henning, E. \& Eiselen, R., 2011, 'New teachers look back on their university education: Prepared for teaching, but not for life in the classroom', Education as Change 15(Suppl 1), 123-142. https://doi.org/10.1080/16823206. 2011.643636

Gravett, S., Morgan, K. \& Henning, E., 2009, The quality of an education system cannot exceed the quality of its teachers, unpublished Expertise report for the UBS Optimus Foundation, Zurich.

Gravett, S. \& Petersen, N., 2017, 'Foundation teachers are more than simply childminders. Here's why', The Conversation, viewed 10 September 2017, from https://theconversation.com/foundation-teachers-are-more-than-simplychildminders-heres-why-71943

Green, W., Parker, D., Deacon, R. \& Hall, G., 2011, 'Foundation phase teacher provision by public higher education institutions in South Africa', South African Journal of Childhood Education 1(1), 109-122. https://doi.org/10.4102/sajce.v1i1.80

Henning, E. \& Gravett, S., 2011, 'Pedagogical craft and its science: Janus-faced in preservice teacher education', Education as Change 15(Suppl 1), 21-33. https://doi. org/10.1080/16823206.2011.643617

Henning, P.N. \& Petker, G., 2015, 'University-affiliated schools as sites for research learning in pre-service teacher education', South African Journal of Education 35(1), 1006-1014. https://doi.org/10.15700/201503070014

Howie, S. \& Van Staden, S., 2012, South African Children's Reading Literacy Achievement - PIRLS and prePIRLS 20111 Summary of the Key results (Media briefing), Centre for Evaluation and Assessment, Pretoria.

Kardos, S.M., \& Johnson, S.M., 2007, 'On their own and presumed expert: New teachers' experience with their colleagues', Teachers College Record 109(9), 2083-2106.

Korthagen, F., Loughran, J. \& Russell, T., 2006, 'Developing fundamental principles for teacher education programs and practices', Teaching and Teacher Education 22, 1020-1041. https://doi.org/10.1016/j.tate.2006.04.022

Lave, J. \& Wenger, E., 1991, Situated learning: Legitimate peripheral participation Cambridge University Press, New York.

Molefe, M., 2014, Personal communication on the number of learners referred for special educational assessments at Gauteng Department of Education's district offices, Johannesburg, South Africa.

National Institute of Child Health and Human Development (NICHD) \& The National Council for the Accreditation of Teacher Education (NCATE), 2006, 'Child and adolescence development research and teacher education: Evidence-based pedagogy, policy, and practice', Summary of Roundtable Meetings, viewed 12 December 2010, from http://www.nichd.nih.gov/publications/pubs/child_adol dev_teacher_ed.pdf

Oduolowu, E., 2009, 'An overview of collaborative teacher preparation programme in a Nigerian University', European Journal of Social Sciences 9(2), viewed 25 January 2011, from http://www.eurojournals.com/ejss_9_2_14.pdf

Rimm-Kaufman, S.E. \& Hamre, B.K., 2010, 'The role of psychological and developmental science in efforts to improve teacher quality', Teachers College Record 112(12), 2988-3023.

Smagorinsky, P., Cook, L.S. \& Johnson, T.S., 2003, 'The twisting path of concept development in learning to teach', Teachers College Records 105(8), 1399-1436. https://doi.org/10.1111/1467-9620.00296

Snow, C., Griffin, P. \& Burns, M.S., 2005, Knowledge to support the teaching of reading: Preparing teachers for a changing world, Jossey-Bass, San Francisco, CA.

Spaull, N., 2011, A preliminary analysis of SACMEQ III South Africa, Stellenbosch Economic Working Papers, Stellenbosch University, Stellenbosch.

Spaull, N., 2016, 'Understanding education in South Africa Inequality, outcomes and resources', paper presentation at RESEP Quantitative Research Conference, University of Stellenbosch, Stellenbosch, South Africa, 19-20 September, 2016.

Stephens, P., Tønnessen, F.E. \& Kyriacou, C., 2004, 'Teacher training and teacher education in England and Norway: A comparative study of policy goals', Comparative Education 40(1), 109-113, viewed 23 April 2010, from http://www. informaworld.com/smpp/content $\sim \mathrm{db}=$ all $\sim$ content=a713616869

Vygotsky, L.S., 1978, Mind in society, Harvard University Press, Cambridge, MA 